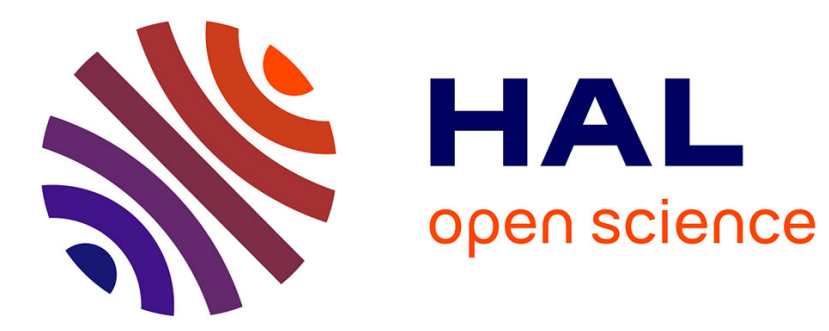

\title{
Similarity in marketing: Scope, measurement, and fields of application
}

Christophe Bezes, Maria Mercanti-Guérin

\section{To cite this version:}

Christophe Bezes, Maria Mercanti-Guérin. Similarity in marketing: Scope, measurement, and fields of application. Recherche et Applications en Marketing (English Edition), 2017, 32 (1), pp.83-105. $10.1177 / 2051570716676258$. hal-02086666

\section{HAL Id: hal-02086666 https://hal.science/hal-02086666}

Submitted on 1 Apr 2019

HAL is a multi-disciplinary open access archive for the deposit and dissemination of scientific research documents, whether they are published or not. The documents may come from teaching and research institutions in France or abroad, or from public or private research centers.
L'archive ouverte pluridisciplinaire HAL, est destinée au dépôt et à la diffusion de documents scientifiques de niveau recherche, publiés ou non, émanant des établissements d'enseignement et de recherche français ou étrangers, des laboratoires publics ou privés. 


\title{
Similarity in marketing: scope, measurement and fields of application.
}

\author{
Christophe Bèzes \\ Professor HDR, Istec* \\ c.bezes@istec.fr \\ * Istec, 12 rue Alexandre Parodi 75010 Paris \\ Maria Mercanti-Guérin \\ Assistant professor HDR, CNAM* \\ Dicen \\ maria.mercanti_guerin@cnam.fr \\ *Cnam, 2 rue Conté, 75003 Paris
}

\begin{abstract}
The concept of similarity is central to marketing research. Its fields of application are very varied. Yet this concept, which is more complex than it seems, is still poorly understood. It must be distinguished from other closely related concepts such as similitude, difference, fit and congruence. This paper shows that the type of similarity used (literal or relational) has different effects on consumers' cognitive processes. This can dramatically alter the results of an experiment. The same applies to the type of measurement used.
\end{abstract}

Keywords: literal similarity, relational similarity, congruence, fit, brand extension. 


\section{INTRODUCTION}

Similarity is widely deployed in marketing. It is used to categorize products, examine the competitive positioning of brands, and assess their ability to expand into other product categories. The operational importance of this concept is reinforced by the fact that many statistical techniques employ it, including principal component analysis, hierarchical groupings, and k-means clustering. Similarity makes it possible to categorize and partition groups of objects, values and data in areas or systems by calculating their proximity, and therefore their degree of similarity.

However, operationalization of similarity in marketing varies markedly from one study to another, for at least three reasons. First, similarity is frequently confused with the concepts of congruence and fit (Maille and Fleck, 2011); indeed, these three terms may occur in the same study without actually being defined. Second, the type of similarity concerned depends on how the stimuli were previously categorized by the researcher. Third, differences may arise depending on whether similarity is measured "objectively", that is to say, determined by a set of shared traits or attributes independent of the observer, or subjectively, based on "no criteria" classifications designed primarily to establish categories (Thibaut, 1997).

Such fluctuating and contingent interpretation of similarity thus makes it difficult to reliably compare the results of different studies. The present paper therefore aims to better define the concept of similarity with regard to closely related concepts (similitude, difference, fit and congruence), to present different practical applications of it, and to show how the conditions of an experiment can alter the type of similarity and its measurement.

\section{SIMILARITY: A CENTRAL BUT DUAL CONCEPT}

\section{A key concept in theories of learning}

Similarity is a basic concept, omnipresent in theories of learning and behavior (Tversky, 1977), and constitutes a heuristic that allows individuals, "in the absence of specific knowledge," to make sound assumptions that will guide them "for action" (Medin et al., 1993: 258). In a complex environment, it makes thinking more effective and faster. The categories that group together similar objects are central to human cognition (Monneret, 2014). The law of similarity governs, for example, relationships based on sympathy and attraction between individuals who have similar personality traits (Byrne et al., 1967). It is for this reason predictive of behavior: "If an organism meets in a new situation elements similar to those to which it has made responses before, it has a tendency to repeat these 
reactions" (Reed, 1927: 111). Hence similarity is frequently mobilized to study consumer behavior (Ratneshwar and Shocker, 1991; Hem and Iversen, 2002), particularly with regard to the categorization of products (Cohen and Basu, 1987) and brand extensions.

Its capacity to guide human behavior is accounted for by its key role in the categorization process, that helps reduce the complexity of the environment (Ratneshwar et al., 2001). Because similar things tend to be grouped together (Medin et al., 1993), similarity makes it possible to identify a category without even having to define it: "Categorization is thus a matter of assessing similarity rather than applying a definition" (Medin and Smith 1984: 117). Moreover, this is why holistic categorization, supported by prototypes, defined as "abstract images embodying features or attributes most commonly associated with members category" (Sujan 1985: 32), or by exemplars (a member of the category that best defines it), is now preferred over analytical categorization from a set of attributes (Sujan et al., 1986; Fiske et al., 1987). Typicality, defined as a close relationship between an object and a category, would also be a "disguised form of similarity" (Medin and Smith, 1984: 117), mediating between similarity and the category (Rips and Collins, 1993).

\section{A dual concept: from literal similarity to relational similarity}

Psychology and marketing long viewed similarity as a "type of comparison" (Medin et al., 1993: 259) for judging a "relation of proximity that holds between two objects" (Tversky, 1977: 347). But the literature now distinguishes two types of similarity: literal (or taxonomic) similarity and relational (or thematic) similarity. The distinction between similarity based on attributes and similarity based on relationships is fundamental (Gentner and Gunn, 2001). Indeed "mental representations consist of hierarchical systems that encode objects [and] attributes of objects" as well as "relations between objects, and relations between relations" (Gentner and Markman 1994: 152). Literal similarity is dominated by the characteristics of objects, whereas non-literal similarity is wider and deeper (Gentner and Gunn, 2001). For example, a Budweiser beer is literally similar to a Budweiser cola, but relationally similar to Budweiser chips, because they are often eaten together (Estes et al., 2012).

\section{The initial conception of similarity: literal similarity}

Literal similarity corresponds to Tversky's (1977) original conception. Formalized in the contrast model, it constitutes a big advance compared to the mental distance model deployed by Shepard (1962) and Rips et al. (1973). Based on the tangible properties of the objects compared, particularly their most salient attributes, it stems from the intuition that the more 
objects share common characteristics, the more similar they are (Tversky, 1977). Attributes are defined here as primitive and indivisible components of stimuli (Medin et al., 1990). Independent of the object, these properties may be concrete or abstract (Gregan-Paxton and John, 1997). Indeed, Tversky (1977: 329) does not deny that these characteristics "may reflect abstract attributes such as quality or complexity"; the physical characteristics of products are nevertheless preponderant. Going beyond mere appearance, which only compares surface attributes, literal similarity compares both the attributes and the proximity relations that generate these attributes. It thus unites Leibniz's (1995) conception and that of mathematicians, who refer to directly proportional geometric and concrete attributes having identical core components.

The preferred categorization tool, literal similarity is the basis for probabilistic theory (Rosch et al., 1976) and the exemplar theory. However, although categorization by Tversky's literal similarity replaced the classical theory, with its greater emphasis on verbalization and causal connections and explanations (Murphy and Medin, 1985), it was soon challenged by other approaches using higher levels of abstraction.

\section{The extended conception of similarity: relational or thematic similarity}

Several research currents have freed themselves from the contrast model, which is deemed too restrictive because overly focused on perceptual (rather than conceptual) characteristics. Indeed, "similarity involves far more than a simple computation over a set of fixed features... (it) aligns features rather than just adding them up" (Medin et al., 1993: 275). The weight of attributes and relationships has a direct impact on the type of similarity used (Goldstone et al., 1991).

The development of a broader concept of similarity goes back to Ortony (1979), who justified it by the incapacity of literal similarity to link fields hitherto considered too remote and too different. By no longer relying on identical attributes, but on "highly similar" ones (Ortony, 1979: 167) or on relationships between attributes or even objects, Ortony (1979: 165) multiplied the degrees of similarity from the most literal form, where all the salient and identical attributes coincide regardless of the context ("Billboards are like placards"), to nonliteral forms such as metaphors ("Billboards are like warts") that may be "irrelevant or inappropriate" in a particular context (Ortony 1979: 162). Even if they do not explicitly refer to them, three non-literal conceptions of similarity follow from Ortony's proposals. 
The theory of conceptual coherence makes good certain deficiencies in the contrast model in terms of categorization. In fact, literal similarity is too sensitive to the weighting of attributes, to the context and to the instructions given during the experiment (Medin et al., 1993). This is why it is "insufficient to provide an account of conceptual coherence" and is therefore unable, in itself, to explain the formation of a category (Murphy and Medin 1985: 289). Building on reasoning by analogy, the theory of conceptual coherence is able to maximize the overlap and conceptual differences between the objects compared. It suggests that the judgment of similarity entails seeking the best possible structural alignment of the information activated: the concept or category should, in its internal structure, have "features connected by structure-function relationships or by causal schemata," and should not contradict the previously acquired knowledge base, at the risk of being "unstable and probably soon forgotten" (Murphy and Medin 1985: 313). Individuals are all the more able to judge similarity because the differences are alignable, that is to say, connected to a common structure (Gentner and Markman, 1997; Goldstone et al., 1991) and more easily remembered (Loken, 2006). Recourse to the structural alignment of differences results in a finer and more secure judgment that the contrast model (Medin et al., 1993). Moreover, for Murphy and Medin (1985: 313) "high within-category similarity and low between-category similarity may be by-products of this internal structure". In the case where the objects compared have few common characteristics and therefore cannot be aligned, relational integration is required (Bassok and Medin, 1997). Two theories make reference to this.

Barsalou confirms the hierarchical structure of ad hoc categories using a relational conception, hence less restrictive than similarity. Based on uses (Ratneshwar and Shocker, 1991; Ratneshwar et al., 2001) or aims (Barsalou, 1983, 1985), this theory assumes that individuals can spontaneously form categories to achieve a goal in a new context. These categories, which are only revealed by a specific context, differ from natural categories because they are not contained in long-term memory (unless they are frequently used) and because they may "include disparate products which seemingly share few or no characteristics" (Ratneshwar et al. 2001: 148) - for example, chips and ice cream as typically anti-diet products (Boush, 1997).

A final approach focuses on an extreme form of relationship: thematic relationships. The essential difference between ad hoc categories and thematic relationships is that the former are organized around a common goal, to which the internal properties of each object (Estes et al., 2012) contribute in a relevant way (Barsalou, 1983). Without this common goal, there is no consistency between these objects. In contrast, thematic relationships are totally external to 
objects and are based on elements that have to play very different and complementary roles in a particular theme or scenario. In this case, complementarity seems almost fortuitous: for example, the unexpected but successful interaction of an iPod and a trainer in the Nike+ range (Estes et al., 2012).

This dual conception (literal and relational) of similarity blurs the boundaries with some neighboring concepts, particularly congruence.

\section{SIMILARITY COMPARED TO CLOSELY RELATED CONCEPTS}

Common sense views judgments of similarity as symmetrically opposed to judgments of difference. This is not the case (Goodman, 1972). In 1913, Hollingworth noted that: "The 'most similar' is not (..) the 'least different,' nor is the 'least similar' identical with the 'most different" (Hollingworth, 1913: 289). Indeed, "similarity is a relationship that combines identity and difference" (Monneret, 2014: 7). Tversky (1977), Medin et al. (1990) and Dubé and Schmitt (1999) thus show that judgments of similarity attribute more importance to common characteristics, whereas judgments of difference focus on the distinguishing points. The former are also more global and less analytical than the latter, making them easier to make, and more natural and more consistent over time (Hollingworth, 1913). The distinction between these two concepts first raises the problem of the measurement scales used to assess similarity as well as difference (Medin et al., 1990). At a more managerial level, it also explains why, depending on whether they are evaluated in terms of similarity or difference, closely related products that share common attributes (Coke and Pepsi rather than fruit juice or beer) will be viewed both as more similar and more dissimilar than others (Johnson, 1981). Conversely, similarity is often erroneously confused with the concepts of similitude, congruence and fit.

\section{Similarity and similitude}

Despite having the same etymology, similarity and similitude are not synonymous. Similitude signifies complete resemblance (identity) between two entities, whereas similarity refers to a near resemblance (Thibault, 1997). Because it is based on a number of similitudes, similarity is more comprehensive than similitude. Moreover, unlike similitude, similarity always implies a subject (the object considered) and a referent (the object to which it is compared). The latter is usually favored for its salience (Tversky, 1977; Dubé and Schmitt, 1999), that is to say, for its intensity and prevalence in the classification used at that time (the "diagnosticity" principle). The obligatory use of a referent explains why, unlike a judgment of similitude in 
mathematics, judgment of similarity in psychology is always "directional" (Tversky, 1977: 328), that is to say, not transitive and asymmetric. A new entrant's positioning strategy by similarity may thus fail when consumers have difficulty allocating "a limited number of clearly identifiable benefits" to the referent leader (Dubé and Schmitt, 1999: 212); a new entrant will, on the contrary, have better chance of success if it capitalizes on a very distinctive single attribute (Cunha and Laran, 2008). Because the asymmetric property of similarity "implies asymmetrical affect transfer" (Boush, 1997: 425), Boush recommends, for example, that a new brand first builds its reputation on the prototypical product of the category before expanding ad hoc to other products in the same category. This property of similarity has also been used in the field of comparative advertising by Horne and Johnson (1987) and in field of the hybrid products by Saaksjarvi and Pulkkinen (2009).

Finally, for the object compared to "come into correspondence" with its referent (Kruhmans 1978: 452), similarity is always constructed by the individual. This ability to influence judgment at will always allow an elderly aunt to detect in a new-born infant a resemblance to her own ancestors (Shanon, 1988).

\section{Similarity and fit}

In the marketing literature, the concept of similarity is almost never defined in relation to related concepts such as congruence and fit. Indeed, it is often confused with them. Yet these are in principle quite distinct concepts.

As a concept (and not as a link between two concepts), fit is almost exclusively used in marketing to assess the desirability of a brand extension, ${ }^{1}$ "Fit is when the consumer accepts the new product as logical and would expect it from the brand" (Tauber, 1988: 28). For this author, it is, along with leverage (the brand's capacity to dominate in the category extension), one of the two conditions for successful transfer of attitude to the extension. But the conception of fit varies greatly from one study to another, since it may represent "a direct or indirect relationship in terms of product type (same technology or manufacturing know-how, complementary products), physical and/or functional attributes, shared targets or consumer benefits, and symbolic evocations (social status, etc.)" (Dimitriadis, 1993: 26).

Early work on brand extensions (Boush et al., 1987) first introduced similarity between product categories to moderate fit, that is, the transfer of affect between overall evaluation of

\footnotetext{
${ }^{1}$ Using an established brand to launch a new product or service in a different category from the parent brand (rather than in the same category: line extension).
} 
the company and the new brand it has created. Indeed, the affect generated by a brand is not enough in itself to ensure the success of an atypical extension. The extension is then less well perceived, because the similarity between the product categories is low and the brand image, even if excellent, is highly specialized.

Some studies, few in number but of considerable interest, maintain this conceptual distinction between similarity and fit, by making the former no longer a moderator but an antecedent of the latter. For Park et al. (1989), judgments of similarity are distinguished from judgments of fit because they operate at the level of products (concrete attributes and functional characteristics), not at brand level (symbolic values and abstract concepts). Like Broniarczyk and Alba (1994), these authors identify two antecedents of fit: one related to the perceived similarity between products or between product categories; the other related to the perception of consistency of the brand extension concept, that is, to the associations induced by the brand. The distinction between similarity, consistency of the concept, and fit explains, in their view, why luxury (rather than functional) brand extensions might present a good fit without there being any similarity of attributes, properties or uses between their original category and the extension category. Extending the work of Czellar (2003), Bèzes and Dubois (2013) show that similarity connects beliefs, whereas fit connects attitudes by making sense of them, in other words, by making a value judgment. Since beliefs are the antecedents of attitudes, similarity could therefore be an antecedent of fit, as in the model developed by Park et al. (1991).

Studies that continue to separate the two concepts also are more cautious than others regarding the role of similarity in brand extensions: except for some products, similarity does not act directly on the evaluation of the extension but indirectly through fit (MacInnis and Nakamoto, 1991, in Cegarra and Merunka, 1993: 66). The impact of fit would be more related to specific associations of the brand compared to its competitors than to similarity (Park et al., 1991; Broniarczyk and Alba, 1994). Indeed, if judgments of similarity are likely to facilitate judgments of fit (Park et al., 1991), Broniarczyk and Alba (1994) doubt that consumers need to make an overall judgment of similarity between the two categories. For these authors, regardless of whether or not the products are similar in terms of attributes, what matters is that they correspond to the expected benefits in a given situation (relational similarity, not literal similarity). Moreover, the more the brand is associated with the attributes of its original product, the less it seems able to be extended beyond its initial category; on the contrary, the more the utility of the brand is recognized, the more it is 
extensible (Rangaswamy et al., 1993). Hence the need to identify the type of similarity at work in this process (Hem and Iversen, 2009).

However, another, still dominant, research current quickly assimilated similarity to fit, though without defining precisely what is meant by similarity (the best known authors include Aaker and Keller 1990, Dacin and Smith 1994, and Brudvig and Raman 2006). The work of Aaker and Keller (1990) and Keller and Aaker (1992) are emblematic of this equivocal, because undefined, conception of similarity. The complementarity of two product categories (capacity to be "consumed jointly to satisfy some particular need") and substitutability (capacity to replace each other and "satisfy the same needs") are the two dimensions used by Aaker and Keller (1990: 30) as constitutive of fit, and therefore similarity. Yet substitutability is based on concrete, therefore literal, similarity whereas complementarity refers to a similarity that is abstract and relational because based on usage or goals (Taylor and Bearden, 2002; Mao et al., 2012). In addition, the conception of fit made in Aaker and Keller fluctuates, since fit is first relational (Aaker and Keller, 1990) and then literal (Keller and Aaker, 1992). Hence the need for Bridges (1989), Bridges et al. (2000) and Seltene (2004), to divide it into product/extension fit based on literal similarity, and image/extension fit, association fit and context fit, based on relational similarity or congruence.

The need to better distinguish similarity from fit, on the one hand, and literal similarity from relational similarity, on the other, thus makes the pioneering contributions of Park et al. (1989, 1991), Broniarczyk and Alba (1994) and Herr et al. (1996) very relevant today in terms of brand extensions.

\section{Similarity and congruence}

The need for conceptual clarification is equally urgent with regard to distinguishing similarity from congruence. However, most examples of congruence studied in marketing concern objects that could not be compared in the context of Tversky's (1977) similarity: a brand and a product (Meyers-Levy et al., 1994), a sponsor and the associated event (Kamins and Gupta, 1984), verbal and pictorial elements in an advertisement (Heckler and Childers, 1992), the image of the user of a product and self-image (Sirgy, 1982), the taste and smell of a food product (Maille, 2007), a piece of music and an advertisement (Kellaris et al., 1993; Galan, 2009), or shops and commercial websites (Bèzes, 2013). 
Theorized by Mandler (1982) and operationalized in marketing by Meyers-Levy and Tybout (1989), congruence is defined "as the descriptive consistency between attributes and associated expectancies, contexts, or schemas" (Kirmani and Shiv, 1998: 44) and incongruence as a "violation of expectation" (Bruner and Postman, 1949: 208). The concept of mental schema ${ }^{2}$ that supports expectations and predictions is therefore central to the concept of congruence (Mandler, 1982; Meyers-Levy and Tybout, 1989): it is in relation to mental schema that one can judge whether congruence is relevant and/or expected. On the other hand, similarity refers more to categories. But schemas are different from categories because they are "spatially or temporally organized structures" (Stayman et al., 1992: 240) that include as categories, "vertical connections between a superordinate (category name) and a subordinate (member)", but also horizontal connections "based on temporal, spatial, and causal relation" (Khan and Paivio, 1988: 558). Moreover, it is the activation of the associated schema that triggers the categorization effort (Pavelchak, 1989).

The second distinction between similarity and congruence concerns the types of stimuli placed in relation to each other. Congruence implies a comparison on an extrinsic basis (rather than intrinsic) to objects and is less concrete than similarity (Leibniz, 1995). Indeed, it involves indirect equivalences between objects that may be of various kinds, while similarity implies a direct comparison between alike and homogeneous attributes or objects, that is to say, of the same kind (Bèzes, 2010). This capacity of congruence to bring together entities of very different kinds is accounted for by its ability to explore deeper structural relations, always by analogy, and therefore with higher levels of abstraction and with fewer shared attributes than similarity (Leibniz, 1995; Ortony, 1979; Gentner and Markman, 1997; GreganPaxton and John, 1997; Bèzes, 2010).

Thus congruence integrates or combines the stimuli present whereas similarity compares them. Through this integration mechanism, the first object presented (the referent) does not bias the judgment of congruence (Cech, 1989), making such judgment symmetrical and transitive, unlike judgment of similarity. With regard to its "relevance", congruence might even in some cases incorporate an earlier judgment of literal similarity (Maille and Fleck, 2011).

\footnotetext{
2 "Schemas are organized knowledge structures representing concepts such as situations, objects, events, and actions at various levels of abstractness. The central functions of schemas are (a) to enable the comprehension of current input and (b) to predict future events" (Schützwohl, 1998: 1183). For example, Meyers-Levy and Tybout (1989) test the incongruence between a traditional soft drink (initial schema) and a soft drink composed of totally natural ingredients.
} 


\section{Synthesis}

Figure 1 shows that most of the concepts discussed above differ mainly with regard to the number of common concrete attributes and common relations they take into account. Similitude concerns a common attribute shared by the two objects compared, while similarity takes into account a bundle of shared concrete attributes, i.e. similitudes. Congruence, for its part, focuses on more abstract relationships between these objects, allowing it to make connections between physically less similar objects. On the other hand, fit is different from congruence because it acts at the level of attitudes, not beliefs. Bèzes and Dubois (2013) take the image of two electric sockets, one male, the other female: although having no common physical characteristic (no literal similarity), they share use properties (congruence) which, as the case may be, can result in a good or a bad fit. On the "attitudes-beliefs" axis, congruence is positioned higher than the literal similarity; it can connect intermediate beliefs (benefits or goals) and thus intervene later in the consumer decision process.

\section{(Insert Figure 1)}

Finally, the extension of the concept of similarity, beyond simply the comparison of attributes (Tversky, 1977), might have made it "meaningless" (Medin et al., 1993: 254, referring to Goodman 1972). Indeed, is not relational similarity simply congruence? Surprisingly, this question has almost never been addressed in the psychology or marketing literature. Only Barsalou (1983), in his experiment 2b, equivocates on the process of developing ad hoc categories: comparison by similarity or another equivalence relation without comparison (such as congruence)?

Apart from this conceptual gray area, a consensus nonetheless emerges around three points that make similarity a "dynamic" process (Medin et al., 1993: 275). 1/ Judgment of similarity is more constructed by the individual than determined by the characteristics of the objects concerned. 2/ A dual similarity model, measured by attributes and/or relations, is favored by psychologists. Indeed, two distinct processes may act within (Bassok and Medin, 1997) or on (Gentner and Gunn, 2001) similarity judgments: one compares the properties of stimuli when they are alignable in one way or another; the other integrates them relationally in a common scenario, especially when these stimuli are not easily alignable. 3/ The nature of the stimuli present affects the cognitive process deployed: comparison and not integration (Bassok and Medin, 1997). 
The concept of similarity is transversal to all marketing policies, from product management to the creativity of processes or products (launch of new products or services) and finally communication. The second part of the paper provides an overview of its use in marketing, distinguishing interpersonal influence from similarity (action on the person), its ability to generate creative new processes variously in communication, brands and products (action on the process), and its contribution to the analysis of new competitive and cultural areas for the company (action on the environment). We then present the main factors influencing the type of similarity used in cognitive processes and the main tools available for measuring it.

\section{AREAS OF APPLICATION OF SIMILARITY IN MARKETING}

Similarity is widely used in marketing as a measure or as a concept. One of its most wellknown applications concerns the analysis of markets and competition. It is also frequently used to study the customer-vendor relationship and brand extensions.

\section{Similarity as the basis for analyses of markets and competition}

Chandon and Strazziéri (1986) emphasize the conceptual link between similarity and the evoked set. Given their similarity, competing brands exert the same attraction and the same array of benefits for the consumer. Pham (1996) thus uses a mapping of similarities in two dimensions (distance and quality) to illustrate four key effects of context in choosing a restaurant (attraction effect, contrast effect, compromise effect and mood effect).

The similarity of markets is also viewed as the prerequisite for an effective internationalization strategy, where it is a matter of identifying similar markets so as to adapt the marketing mix to these areas and to achieve economies of scale. Hofstede et al. (2002) segment international markets by predefining geographical areas, which are assumed to be homogeneous in terms of lifestyle, value and therefore consumption behavior. Using a hierarchical Bayesian approach, they develop a general model. Similarly, Douglas and Craig (1996) analyze the similarities between geographical units and business portfolios. For these authors, the signs of good cross-market similarity lie in consumer behavior (tastes, interests, purchases) and an identical environment (regulation, distribution, infrastructure, advertising). Grein (2000) provides a measure of the similarity between markets based on the assessment of per capita GDP and a cultural proximity score adapted from the work of Hofstede. It shows that advertising and the determination of prices are the variables of the mix most influenced by the similarity of markets. From a more organizational standpoint, Kim and 
Parkhe (2009) make a distinction between competing and cooperating similarity. They propose a measurement scale with four dimensions (cultural context, national context, corporate context, managerial practices).

On the consumer side, the study of competition uses three key concepts: substitutability, similarity and competition intensity based on the consideration set (Mercanti-Guérin, 2010). While substitutability varies according to the use situation envisaged by the consumer, similarity on the other hand is in stable from one situation to another and is based on the asymmetry between brands. This asymmetry is related to the fact that brands in the same market are viewed as subsets of attributes of the prototypical brand. The research here mainly explores the relationships of similarity from the angle of competition and its influence on decision heuristics.

Although the judgments of preference cannot be equated to judgments of similarity, some authors consider that they strongly influence each other (Derbaix and Sjöberg, 1994). However, judgments of preference among consumers are based on the analysis of utilitarian or hedonic benefits, while judgments of similarity are based on analysis of the product's physical attributes (Creusen and Schoormans, 1997). Even though these authors do not allude to it, this result may illustrate to what extent literal similarity centered on the concrete attributes of the objects considered does not act at the same level of consumers' elaboration and decision process as relational similarity focused more on benefit and goals. Literal similarity is likely to constitute a core belief, whereas relational similarity is a more subjective intermediate belief, which explains the high degree of affectivity identified by Collange (2005) in preference judgments. Because, for this reason, the most literally similar brands are not necessarily the most competitive, Chandon and Strazziéri (1986) recommend using, in a combinatorial way, competitive perceptual maps and perceptual maps based on similarity.

In the field of communication too, similarity is considered to be a key variable in competition between brands. The study by Poncin et al. (2006) based on the theory of assimilationcontrast shows that advertisements placed in the same advertising screen are all the more competitive because they are perceived as similar. This proves that positive reactions associated with both the pleasure dimension and the excitement dimension are influenced by the emotional reactions triggered by the previous advertisement in the case of dissimilar ads. In addition, the stronger the involvement in relation to the product, the more the advertisements are processed systematically and the more similarity and dissimilarity are viewed as important. Law (2002) in turn analyzes the repetition of brand slogans perceived as 
similar and their impact on memory. This author highlights the memory confusion induced by repeated slogans of two similar brands and emphasizes the importance of his results in a competitive environment leading to me-too product launches. The repetition of advertisements in a crowded market environment thus has the effect of mutually neutralizing competitors.

Schweidel et al. (2006) investigate how to develop the communication of a brand over time and in relation to the competition, while maintaining the specific attributes that have made it strong (advertising sagas). They provide a model for measuring similarity that considers a similarity score derived from advertisements presented in pairs, an evaluation of the distance between the advertisement items, and the central core (specific items retained regardless of the communication). Only three dimensions appear to be explanatory of the perception of similarity between advertisements: humor, product characteristics and the impression of continuity between the advertisements.

Similarity is also used in comparative advertising - defined as advertising that copies specific product attributes with the aim of linking the physical characteristics of the new brand to those of the dominant brand (Wilkie and Farris, 1975). Comparative advertising is more effective in diverting purchasers of a dominant brand to a new brand than imitation of its packaging or product attributes (Dröge and Darmon, 1987). Using the contrast model, Johnson and Horne (1988) show that comparative advertising reinforces associations between brands and increases their perceived similarity.

While the literature lays emphasis on the use of similarity by traditional media, the Web also makes it a central concept in the construction of social and personalized recommendation algorithms. Such construction uses a multidimensional measure of similarity based on individual criteria in terms of age and gender (Gefen and Straub, 1997) or in terms of buying motives (Hassanein and Head, 2006). As well as literal similarity, it also takes into account more relational similarities, by comparing navigation routes, searches carried out and websites visited. Similarity is thus used to recommend the purchase of keywords: algorithms, such as those used by Google Adwords, calculate contextual similarity indices between keywords purchased by advertisers and the Web pages that will display the advertisements. It is also mobilized to put display advertising on websites: advertisers' banners are addressed to users who have shown an interest in similar websites in terms of products or content. More 
recently, the look-alike modeling ${ }^{3}$ has extended behavioral targeting to prospects who are most similar to good customers.

\section{Interpersonal similarity: an object of study with multiple applications}

Another field of application of similarity in marketing concerns interpersonal similarity, which is one of the main causes of felt attraction between two individuals. Interpersonal attraction comprises several dimensions, including perceived intelligence, desirability and physical proximity (Byrne and Griffith, 1973). Mobilized in marketing for product design, distribution, communication and sales force management, interpersonal similarity has been the subject of quite disparate research in terms both of measurements and conclusions. It has been studied from a strictly interpersonal standpoint (similarity between consumers) and from a more transitive angle (similarity between consumers via the product or similarity between consumer and brand representatives). Here we give it a broader relational status: the relationship between customers, between customers and the sales force, and between individuals and avatars.

The effects of the similarity between two individuals are relatively easy to demonstrate. The similarity-attraction hypothesis posits that similar people enjoy being together (Nass et al., 1995). Nevertheless, the effects of interpersonal similarity are not always positive. Swartz (1984) shows that there is no relation between the perceived expertise of the sender and perceived similarity with the receiver. This lack of relation needs to be qualified in accordance with the product category. In the area of cosmetics, the perception of weak similarity with the model used in the advertisement results in low perceived expertise. For more technological products that have little connection to the body, such as buying a TV, there is a link between low expertise and strong similarity, as if the expert were little different from the novice. Lastly, Bourcier-Bequaert and De Barnier (2014) find that similarity in subjective age between a model in an advertisement and older female consumers has an indirect effect on brand attitude, and that this effect is enhanced when consumers can easily identify with an "ordinary" model.

With regard to purchasing context, the mere presence of consumers similar to oneself influences the satisfaction obtained from shopping, via a process that is both emotional and cognitive (Kwon and Ha, 2013). Zhang et al. (2014) explore how social factors can influence store visits. They show that customers' contacts with other customers, as well as with sales

\footnotetext{
${ }^{3}$ Literally, modeling based on the slogan "Your best prospects resemble your best customers".
} 
staff, alter their purchase time and route. The purchase process is more influenced by customer-customer interactions than by customer-sales staff interactions. However, in the case of customer-sales staff interactions, perceived similarity with the sales assistant (particularly in terms of age, gender and ethnicity) has an influence on purchasing behavior. Jiang et al. (2010) thus show that the so-called incidental similarity between consumers and sales staff (sharing the same first name or date of birth, living in the same neighborhood) has a positive influence on attitudes and purchase intentions in stores. When age or ethnicity is similar, customers have less physical contact with the product. They experience a lesser need for reassurance, which is not the case for identical gender. Such influence is moderated by the type of interactions between customers and the number of customers in the point of sale. With regard to product design, Damak (1997) makes morphological measurements (real and perceived) in connection with the design of perfume bottles. Her research confirms the tendency to prefer physically similar shapes among individuals who have a positive body image (self-concept) and different or complementary shapes among those who have a negative image (desire for the perceived self to be closer to the ideal self). While is still possible to speak of similarity in Damak's study, it is more appropriate to speak of congruence (Sirgy, 1982) in research dealing with the image of a product and the selfconcept, since the objects compared are not at all alike.

Individual-website interfaces also make use of similarity in their new conceptual approaches. Similarity can thus be seen as physical similarity, similarity of movement ${ }^{4}$ (the same way of moving for the individual and his/her avatar) and social similarity (the same sense of social belonging between the avatar and the individual). This extended similarity involves an anthropomorphic view of the object compared to the individual (Nowak, 2004). Internet users tend to personify their computers (Moon, 2000), hence the tendency to socialize and humanize contacts on websites so as to enhance the online experience (Lemoine and Cherif, 2012). For this reason relationships between consumers and avatars are studied in terms of interpersonal similarity. David-Ignatieff (2012) shows that perceived similarity in age between the consumer and the avatar influence purchase. ${ }^{5}$ Nass et al. (1995) found that internet users prefer avatars with the same ethnic appearance as themselves, which give them

\footnotetext{
${ }^{4}$ Similarity of movement is difficult to manipulate and its effects follow an inverted $\mathrm{J}$ curve. The more a robot looks like a human being, the more positive the emotions, up to the point at which one leaves similarity and approaches a more or less perfect imitation of individuals. Negative feelings then grow, and focus on the few remaining differences, which are judged very severely (Mori 1970).

5 Perceived similarity with an avatar is also designated by the term homophily (McCroskey and Richmond, 1979; Lemoine and Cherif, 2012). Lazarsfeld and Merton (1954) define homophily as the degree of perceived similarity between the observer and the agent observed. David-Ignatieff (2012) distinguishes two types of homophily: status homophily (age, gender, religion, job) and homophily of values and attitudes.
} 
more confidence and strengthen the quality of their posts to a greater extent than in the case of less similar avatars.

Generating interpersonal similarity is thus a real challenge for online sales sites, as well as for retailers and their sales forces. This challenge leads them to create new forms of interaction and to devise other forms of communication and retailing.

\section{Similarity as a source of creativity in marketing}

Similarity is increasingly used by practitioners to give coherence to their marketing policy in the context of product launches, adoption of novel forms of communication, and brand or distribution channel extensions. It can even be considered as a foundation for creativity. A creative consumer is someone who has a dense cognitive network, enabling him/her to make connections between concepts (Hirschman, 1980). The inter-concept network is measured by giving the consumer a varied list of representative products from different areas of consumption (transport, leisure, food). The products are arranged in pairs, and the participants are asked to list similarities and resemblances in each pair. The more consumers are able to detect links of similarity or "dissimilarity" between the products or the different attributes of the products, the more creative they are deemed to be, because their ability to resolve a possible consumption problem is increased by their capacity to make the most comprehensive possible comparison among the various products and to choose a superior product. An experienced consumer thus has a more developed inter-concept network than a less experienced consumer. Product-linked creativity is supported in part by Mednick and Mednick's (1962) associationist model. Described as a way to reach a creative solution, creative similarity is viewed by these authors as the foundation of arts such as rhetoric and music.

Gill and Dubé (2007) consider the creation of new product concepts from the combination of two already existing product concepts. New product concepts created by relationally combining existing concepts are more rapidly and easily interpreted than those created by literally combining the concepts. Among the concepts created literally, those that combine or modify the functions of two types of products (rather than their non-functional features) are more difficult to interpret. Standard hybridization today of technology products therefore poses cognitive problems for consumers; companies should obviate these by investing more in explanation and advertising.

Another application of similarity in the area of creativity concerns the co-creation of products. Thompson and Malaviya (2013) examine the conditions in which an advertisement 
whose creation has involved consumers is effective among consumers not involved in its conception. In general, such initiatives are subject to skepticism with regard to the cocreators' competence. Emphasizing co-creator consumers has a positive effect only on consumers with limited cognitive resources who are very loyal to the brand and share some common characteristics with the co-creators.

But with regard to the creation of new products, similarity is mainly used in line and brand extensions. This topic has been widely addressed with a view to conceptually distinguishing similarity and fit; here we address it again, this time when the variables determining the mechanisms of similarity and its effects are examined.

\section{MEASUREMENT OF SIMILARITY AND THE FACTORS THAT INFLUENCE IT}

\section{Measurement of similarity}

The methods for measuring similarity are almost as varied as its applications. They may be indirect qualitative or quantitative methods which, from common traits or dimensions, are used to analyze similarities between the objects compared. They may also be direct, more subjective, methods that use scales to measure a more specific overall similarity or similarities (literal or relational). If indirect measures appear more objective, they nevertheless have the disadvantage of taking into account antecedents of similarity that the individual would not necessarily have considered at the outset (Maille and Fleck, 2011)

Table 1 provides a non-exhaustive overview of these measurement instruments by areas of application. It excludes tools that do not explicitly refer to the concept of similarity, but instead to the concepts of congruence or fit. For this reason, the studies by Aaker and Keller, for example, are not here listed here, whereas they are in the summary provided by Estes et al. (2012), to which the reader is referred.

\section{(Insert Table 1)}

Studies on brand extensions are the only ones to use measurement scales alone. However, those concerned with the other areas listed in Table 1 (market analysis, interpersonal similarity, cross-culturalism) use indirect as well as direct measures. This diversity of measuring similarity independently of the area studied is undeniably an opportunity for enrichment and deepening their studies for researchers able to combine or link these 
measures. In addition, SEO techniques ${ }^{6}$ on the web now rely on similarity indices. Their aim is to distinguish original content from copied or plagiarized content, which is of little interest to search engines such as Google. These methods, which analyze sets of words, have points in common with the semantic analyses used in marketing and dealing with similarity: they analyze sets of words ${ }^{7}$ and highlight the similarities between two web pages.

This extreme diversity of tools can nevertheless be a source of complexity, leading to unexplained differences in results depending on the method used. But apart from the divergence of measurements, these differences may be attributable to personal or contextual factors.

\section{Personal or contextual factors that influence the type of similarity used}

Several factors are likely to alter the perception of similarity as well as its impact on consumer behavior.

- How the stimuli are presented. For example, the more stimuli are presented as images rather than described verbally, the more their distinguishing characteristics gain in importance (Medin et al., 1990).

- The type of comparison requested and the focal option that imposes a direction, that is to say, the choice of a subject and a referent (Tversky and Gati, 1982).

- The situation (Barsalou, 1983; Corfman, 1991; Schmitt and Dubé, 1992).

- People's personal characteristics (Sujan, 1985; Alba and Hutchinson, 1987).

The types of similarity judgments used to evaluate brand extensions concretely illustrate these points.

First, the object categories to be compared in an experiment may unintentionally skew the results by orienting respondents to a particular type of similarity. Consumers turn to relational similarity when they need to connect object categories that are distant in terms of content and when the parent brand of these products is prestigious (Monga and John, 2010). Indeed, this linking process involves examining more abstract elements (Johnson, 1984; Gentner, 1988; Ozanne et al., 1992; Markman and Wisniewski, 1997). A symbolic parent brand may thus more easily be extended to symbolic product categories. Consumers then set

\footnotetext{
${ }^{6}$ Search engine optimization includes all techniques that improve the position of a website in the results of search engines such as Google or Bing.

${ }^{7}$ The index generally used is the one developed by Jaccard, which allows exploration of the similarity between objects constituted by binary attributes and particularly sets of objects. The index involves dividing the number of objects common to both sets by the number of distinct objects. The SEO tools Webrankinfo and Seoquake thus provide calculations of similarity.
} 
out from the abstract, that is to say, the memorized characteristics of the parent brand, in order to evaluate the extension products (top-down evaluation): Park et al. (1989) give the example of Gucci, which as well as bags and perfumes also markets pens. However, if the parent brand sells functional products, consumers consider the relevance of the extension, looking at the literal similarity between the concrete attributes of the brand's products (bottom-up assessment): Park et al. (1989) give the example of Honda, which markets products whose common point is their fuel efficiency (motorcycles, compact cars, etc.).

Second, the process of the experiment, including the time available for comparing the objects, may also induce participants to favor a particular type of similarity. Time pressure encourages recourse to relational similarity based on holistic judgment, which is more affective and deemed faster than the literal similarity, which is more selective but also slower to implement (Monga and John, 2010). This advantage of relational similarity is explained by its conformity to an already established mental schema, fed by past experiences, and by the fact that affective reactions of preference, pleasure and displeasure precede other forms of cognitive evaluation (Zajonc, 1980). By virtue of being holistic and therefore more economical in terms of cognitive resources, judgments of relational similarity precede other, possibly more analytical assessments (Fiske et al., 1987). This situation inevitably results in brand extensions being seen as more familiar and less novel and being evaluated more positively (Estes et al., 2012).

Third and last, the choice of participants can considerably affect results from one experiment to another. Even if they are all able to make literal and relational judgments, their personal characteristics may make them favor a particular type of similarity. People of Asian or Mediterranean origin are thus more prone to use relational similarity because they are more flexible, more interdependent (Ahluwalia, 2008) and tolerate ambivalence better (Thompson and Zanna, 1995). Conversely, in decontextualizing the object, Western cultures place more emphasis on literal similarity. More individual factors may also apply. The more consumers are educated, expert, involved and goal-oriented, the more they rely on literal similarity (Alba and Hutchinson, 1991). Furthermore, men seem to be more able than women to mobilize relational similarity, which why they judge more favorably than women a dissimilar extension introduced by a functional brand (Monga and Gürhan-Canli, 2012). If people are in a good mood when exposed to the extension, they are more likely to prefer judgments of relational similarity, whereas being in a bad mood makes them more analytic, and therefore more critical toward the extension, and this in turn encourages the use of literal similarity (Sar et al., 2011). 
If these personal and contextual variables are not taken into account, the contingency of the results with regard to the experimental conditions makes it difficult to interpret the study. For example, the analysis by professionals of 54 real brand extensions shows that literal similarity accounts for $16-17 \%$ of the variance of their evaluation, whereas relational similarity accounts for $25 \%$ (Estes et al., 2012). This result can be interpreted in four ways: either it is easier to extend a brand using abstract associations (relational similarity), especially when the brand name is typical, that is, strongly associated with a category (Heineken rather than Ralph Lauren, in the example given by Batra et al 2010); or most of the extensions evaluated in this study concern remote product categories and products that are more symbolic than functional; or the time for evaluation was very limited; or quite simply, that the evaluators were men, of eastern origin, with little expertise, relatively uninvolved, and in an excellent mood!

\section{CONCLUSION}

While many applications in marketing make use of similarity, its scope and mechanisms of similarity are no less mysterious (Medin et al., 1993). With a view to using this concept better in future research, the present study has sought to clarify two important points.

The first concerns the delimitation of the concept of similarity in relation to concepts that are very close to it. A review of the marketing and psychology literature has shown that similarity is not the exact inverse of difference, a fact that inevitably poses problems of measurement in terms of distance or proximity. ${ }^{8}$ Next, similarity lies upstream of the consumer decision process, that is to say, at the level of basic beliefs, while fit lies downstream, at the level of attitudes. Moreover, fit is a transfer of affect and not a comparison. Finally, in its literal conception, similarity only allows objects of the same nature to be linked on the basis of specific characteristics whereas congruence, which is based on more abstract relations, links objects of very different kinds. These conceptual distinctions, that complement the work of Maille and Fleck (2011) on congruence, should help future researchers to choose the concepts most suited to their problematic.

The second contribution concerns the fact that there are two main types of similarity - literal similarity and relational similarity - the latter being close to and at times confused with congruence. Literal similarity, historically the best known and the most frequently used, is

\footnotetext{
${ }^{8}$ In Gestalt theory, the law of similarity states that our brain combines elements that appear similar, that is to say, which share a number of properties. It differs from the law of proximity, with regard to which the brain combines elements that often appear together, in the same perceptual area.
} 
based on an analytical comparison judgment of the attributes or specific properties of the objects concerned. These objects are considered to be all the more similar since they are of the same nature, that is to say, they belong to the same category. However, this type of similarity always strengthens differences (Medin et al., 1990). In contrast, relational similarity (probably congruence) can link objects of different kinds, by referring to an established schema and activating an analogical thought process based on extrinsic elements. It accentuates similarities (Gentner and Gunn, 2001) and promotes faster and often more favorable assessment of the stimuli involved.

Although this distinction is not recent, few studies in marketing draw all its methodological and managerial implications.

- Most existing scales, mainly in the area of brand extensions, confuse these two concepts rather than distinguish them, which further detracts from an understanding of the phenomenon being addressed. The relatively easy creation of distinct measurement scales to evaluate literal similarity on the one hand and relational similarity on the other thus fill a certain lacuna.

- A research project may be skewed by the choice of objects presented as well as by the profile of the respondents or by methodological guidelines that inadvertently favor a particular type of similarity. This adds to the bias associated with the asymmetric nature of the concept of similarity, which leads respondents to choose as the primary referent the first object presented or the one they were familiar with earliest (Cunha and Laran, 2008).

- Literal similarity and relational similarity draw on different cognitive processes (analytical comparison for the one, holistic integration for the other). But any comparison involves viewing the objects concerned as relatively close substitutes. A link between literal similarity and substitutability is also noted by Aurier (1993). Such a link increases the potential risk of cannibalization, since a substitution brand similar to the original brand benefits from a better image than the original (Collange, 2005). Conversely, the integration of these objects into an overall judgment (relational similarity) allows the consumer to think of these objects as complementary, which places the emphasis more on possible cross-fertilization (Estes et al., 2012). Mao et al. (2012) also establish a link between literal similarity (relational) and substitute similarity (complement).

- Well exploited, this distinction can lead to extremely instructive applications in the are of line and brand extensions. Literal similarity here seems to be more relevant for 
studying brand and even more so line extensions, which are closely associated with the attributes of the original product. For example, extensions based on the "Fruit image" of the Andros brand are of this type (expertise in fruit preparation processes and the extension of this product line into the nearby area of jams, dairy products and beverages). In contrast, relational similarity is more suitable for analyzing remote brand extensions: for instance, Weight Watcher or Taillefine (low calorie products) that develop in different markets with no real connection with each other, relying solely on a brand image centered on dietetics. Distinguishing literal similarity and relational similarity can therefore enable managers to manage brand extensions differently (Hem and Iversen, 2009), for example by reducing the duration and repetition of commercials for relationally similar extensions (Estes et al. 2012).

Further studies should therefore make clear what kind of similarity is being used, the reasons for this utilization, and the consequences for the results of this conceptual and methodological choice. Indeed, "if the definition and measurement of similarity is ambiguous, the role of similarity in the transfer of knowledge and affect must also be ambiguous" (Martin and Stewart, 2001: 472). 
Figure 1. Conceptual difference between similitude, similarity, congruence and fit

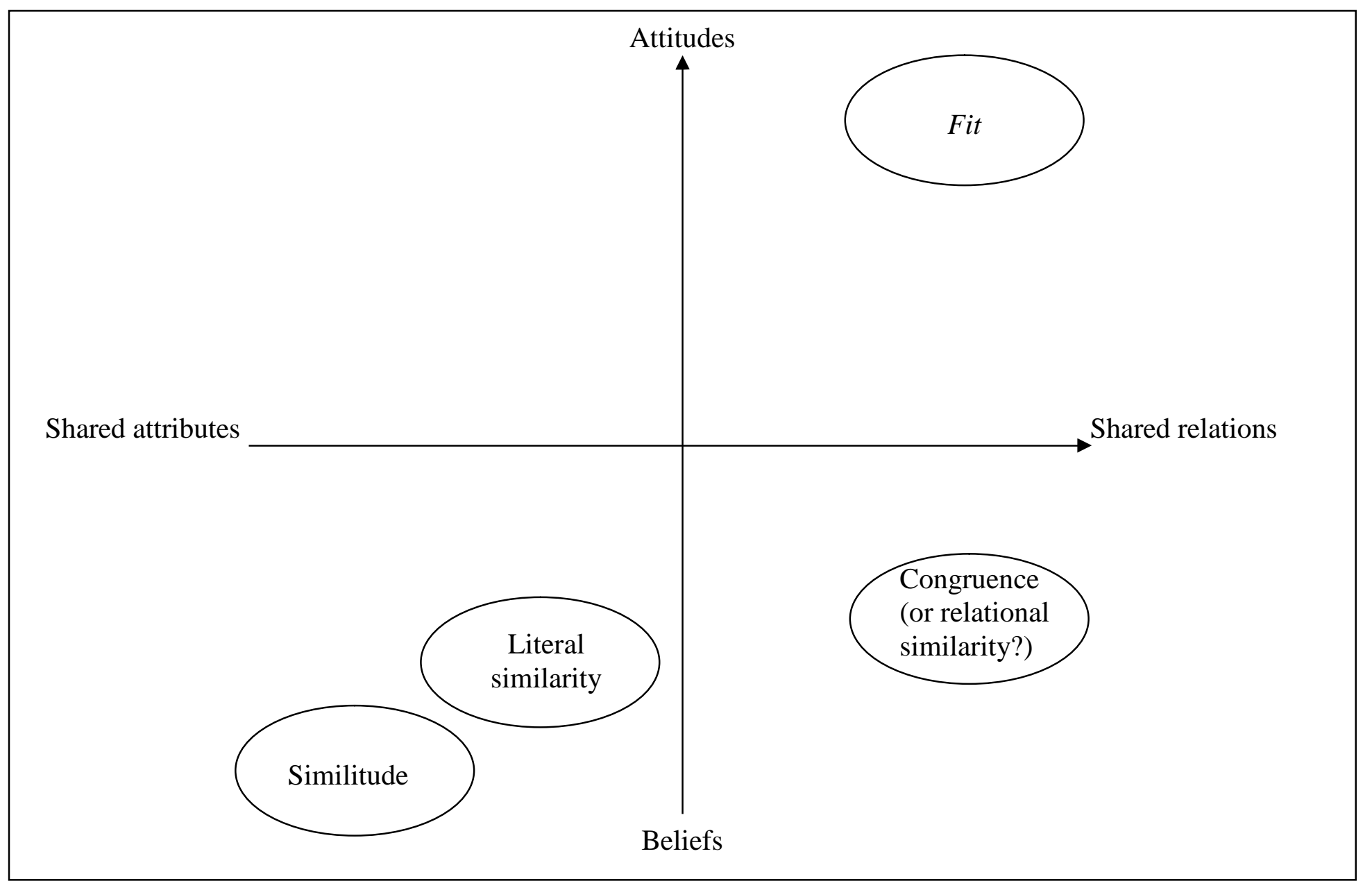


Table 1. - Non-exhaustive overview of the main measures of similarity in terms of areas of application in marketing

\begin{tabular}{|c|c|c|c|c|}
\hline Authors & Research topic & Main hypothesis & $\begin{array}{l}\text { Operationalization of the } \\
\text { measure }\end{array}$ & Limitations \\
\hline \multicolumn{5}{|c|}{ Measures of similarity: the sectoral approach } \\
\hline Kim and Parkhe (2009) & $\begin{array}{l}\text { Analysis of corporate } \\
\text { alliances. }\end{array}$ & $\begin{array}{l}\text { Alliances between firms too } \\
\text { similar in terms of resources } \\
\text { and market coverage } \\
\text { (competitive similarity) } \\
\text { produce a negative result in } \\
\text { contrast to cooperative } \\
\text { alliances based on similarity } \\
\text { (same cultural basis, same } \\
\text { national origin, same } \\
\text { management practices). }\end{array}$ & $\begin{array}{l}\text { Sample of } 70 \text { American firms } \\
\text { in the chemical, electronic and } \\
\text { electrical industries. } \\
\text { Use of a multi-item } \\
\text { measurement scale to measure } \\
\text { competitive similarity and } \\
\text { several constructs to measure } \\
\text { cooperative similarity. }\end{array}$ & $\begin{array}{l}\text { Splitting measures of } \\
\text { cooperative similarity into } 4 \\
\text { different constructs does not } \\
\text { really allow a comparison with } \\
\text { the construct of competitive } \\
\text { similarity, which by contrast is } \\
\text { fully aggregated. }\end{array}$ \\
\hline Hofstede et al. (2002) & $\begin{array}{l}\text { International segmentation of } \\
\text { markets: application to the } \\
\text { image of butcher's shops in } \\
\text { Europe. }\end{array}$ & $\begin{array}{l}\text { Spatial similarities between } \\
\text { regions determine the } \\
\text { similarity of perceptions and } \\
\text { needs of consumers. }\end{array}$ & $\begin{array}{l}\text { Hierarchical Bayesian } \\
\text { approach with specification of } \\
\text { spatial dependence levels. } \\
\text { Comparative test of } 4 \\
\text { prediction models. }\end{array}$ & $\begin{array}{l}\text { Field study carried out in } \\
\text { Europe with countries and } \\
\text { regions that share a } \\
\text { "significant historical culture" } \\
\text { and that may have in principle } \\
\text { favored the segmentation a } \\
\text { priori. }\end{array}$ \\
\hline Grein (2000) & $\begin{array}{l}\text { Analysis of car manufacturers' } \\
\text { international marketing } \\
\text { strategies. }\end{array}$ & $\begin{array}{l}\text { The more similar the countries, } \\
\text { the more similar are the } \\
\text { manufacturers' marketing } \\
\text { strategies. }\end{array}$ & $\begin{array}{l}\text { Calculating an overall score } \\
\text { incorporating different } \\
\text { elements (GDP per capita, } \\
\text { trade between countries, etc.) } \\
\text { then the Euclidean distance for } \\
\text { each pair of countries } \\
\text { compared. }\end{array}$ & $\begin{array}{l}\text { Consideration of mainly } \\
\text { macroeconomic variables. }\end{array}$ \\
\hline $\begin{array}{l}\text { Creusen and Schoormans } \\
\text { (1997) }\end{array}$ & $\begin{array}{l}\text { Analysis of the effects on } \\
\text { preferences of different types } \\
\text { of similarity. }\end{array}$ & $\begin{array}{l}\text { Preference judgments are } \\
\text { influenced more by profits or } \\
\text { image attributes while } \\
\text { similarity judgments are more } \\
\text { influenced by the specific } \\
\text { characteristics of the products. }\end{array}$ & $\begin{array}{l}\text { Qualitative study of } 89 \text { people } \\
\text { and two types of products. }\end{array}$ & $\begin{array}{l}\text { No comparison of the effects } \\
\text { of literal similarity based on } \\
\text { the specific attributes of } \\
\text { objects and of relational } \\
\text { similarity based on image } \\
\text { attributes and benefits. }\end{array}$ \\
\hline Green et al. (1978) & $\begin{array}{l}\text { Definition of preferences with } \\
\text { regard to holiday locations }\end{array}$ & $\begin{array}{l}\text { Using conjoint analysis to } \\
\text { identify preference groups }\end{array}$ & $\begin{array}{l}\text { Ranking seven holiday } \\
\text { locations (group 1). }\end{array}$ & $\begin{array}{l}\text { Limitations in terms of scores } \\
\text { assigned (inter rater validity), }\end{array}$ \\
\hline
\end{tabular}




\begin{tabular}{|c|c|c|c|c|}
\hline & & $\begin{array}{l}\text { based on the similarity of } \\
\text { perceptions. }\end{array}$ & $\begin{array}{l}\text { Ranking of six attributes into } \\
\text { three levels according to their } \\
\text { perceived similarity with the } \\
\text { place (group 2). } \\
\text { Submission of } 18 \text { holiday } \\
\text { location profiles (group } 3 \text { ) and } \\
\text { use of conjoint analysis. }\end{array}$ & $\begin{array}{l}\text { external validity and choice of } \\
\text { attributes. }\end{array}$ \\
\hline Jain and Pinson (1976) & $\begin{array}{l}\text { Revealing the importance of } \\
\text { the order of stimuli, } \\
\text { respondents' attention and } \\
\text { involvement in judgments of } \\
\text { similarity. Similarity } \\
\text { judgments concern a sample of } \\
\text { eight US cities. }\end{array}$ & $\begin{array}{l}\text { The order of presentation of } \\
\text { comparison by product pairs of } \\
\text { different weights for each } \\
\text { dimension. Also, increasing } \\
\text { people's level of attention } \\
\text { leads to an artificial increase in } \\
\text { the weight of each perceived } \\
\text { dimension. }\end{array}$ & $\begin{array}{l}\text { Using the INDSCAL model } \\
\text { (individual difference scaling) } \\
\text { on } 136 \text { respondents. This } \\
\text { model allows the study of } \\
\text { differences between raters. }\end{array}$ & $\begin{array}{l}\text { No difference in judgment of } \\
\text { similarity for any of the } \\
\text { operations performed (order, } \\
\text { attention, involvement). How } \\
\text { to operationalize these three } \\
\text { variables is discussed and } \\
\text { presented as not very relevant. }\end{array}$ \\
\hline Neidell (1972) & $\begin{array}{l}\text { Measures of similarity applied } \\
\text { to the pharmaceuticals market. }\end{array}$ & $\begin{array}{l}\text { Using comparison by pairs to } \\
\text { generate similarity indices and } \\
\text { comparison with the anchor } \\
\text { points method. }\end{array}$ & $\begin{array}{l}\text { Experiment 1: choice of two } \\
\text { drugs from three considered } \\
\text { most similar and two } \\
\text { considered less similar to each } \\
\text { other (differential semantics). } \\
\text { Experiment 2: submission of a } \\
\text { measurement scale by } \\
\text { stimulus, rating each product } \\
\text { on each scale (anchor point). } \\
\text { The stimuli are generated by } \\
\text { respondents. }\end{array}$ & $\begin{array}{l}\text { Ratings problem in experiment } \\
1 . \text { Experiment } 2 \text { is richer in } \\
\text { terms of indications on } \\
\text { products but only works for a } \\
\text { limited number of stimuli }(\mathrm{n}= \\
10) .\end{array}$ \\
\hline Fry and Claxton (1971) & $\begin{array}{l}\text { Measuring the similarity of } 12 \\
\text { cigarette brands. }\end{array}$ & $\begin{array}{l}\text { Use of semantic differential } \\
\text { analysis and direct similarity } \\
\text { judgments. Comparison of the } \\
\text { two methods. }\end{array}$ & $\begin{array}{l}\text { Selection of } 216 \text { smokers from } \\
\text { London. Measuring the } \\
\text { similarity of } 12 \text { cigarette } \\
\text { brands, selection of four } \\
\text { brands among the } 12 \\
\text { considered least similar in } \\
\text { terms of image. Semantic } \\
\text { differential analysis of the four } \\
\text { brands selected. } \\
\text { Use of TORSCA } \\
\text { multidimensional analysis } \\
\text { software. }\end{array}$ & $\begin{array}{l}\text { Strong congruence between } \\
\text { the two measurement methods. } \\
\text { Methods considered } \\
\text { complementary rather than } \\
\text { mutually exclusive. } \\
\text { Limitations of differential } \\
\text { analysis lie in the estimation of } \\
\text { measurement intervals and the } \\
\text { risk of missing a dimension. }\end{array}$ \\
\hline
\end{tabular}




\begin{tabular}{|c|c|c|c|c|}
\hline Johnson and Hudson (1996) & $\begin{array}{l}\text { Evaluation of user perception } \\
\text { of market analysis methods. } \\
\text { Two methods are evaluated: } \\
\text { the spatial method to assess } \\
\text { similarity of brands and } \\
\text { products on a map and the } \\
\text { clustering or classification } \\
\text { method. }\end{array}$ & $\begin{array}{l}\text { Spatial representation of } \\
\text { similarity is more intuitive and } \\
\text { better assimilated by managers } \\
\text { than representation by } \\
\text { classification. } \\
\text { The two methods are } \\
\text { complementary in their } \\
\text { approach to similarity. Spatial } \\
\text { representation can assess } \\
\text { competition between brands of } \\
\text { the same category, while } \\
\text { classification methods shed } \\
\text { light on competition between } \\
\text { the categories themselves. }\end{array}$ & $\begin{array}{l}\text { Phase 1: subjects were } \\
\text { classified by six pairs of } \\
\text { stimuli, each corresponding to } \\
12 \text { products or services. } \\
\text { Phase 2: different maps and } \\
\text { classifications were developed. } \\
\text { A scale for measuring the } \\
\text { perceived utility of the two } \\
\text { methods was tested using a } \\
\text { second sample. } \\
\text { The results show that both } \\
\text { types of analysis are perceived } \\
\text { as more helpful for } \\
\text { competition between brands } \\
\text { than between categories. } \\
\text { Furthermore, prior familiarity } \\
\text { with the brands or categories } \\
\text { analyzed influence the } \\
\text { perceived usefulness of the two } \\
\text { types of study. }\end{array}$ & $\begin{array}{l}\text { Restriction of results to } \\
\text { competitive analyses. } \\
\text { Stimuli chosen sometimes too } \\
\text { prototypical, which gives } \\
\text { solutions based on the } \\
\text { categorization an advantage } \\
\text { over spatial methods. }\end{array}$ \\
\hline Wilkes and Wilcox (1977) & $\begin{array}{l}\text { Questioning the validity and } \\
\text { reliability of similarity } \\
\text { judgments. Comments on a } \\
\text { study by Summers and } \\
\text { MacKay (1976) on the } \\
\text { automotive market and campus } \\
\text { locations. }\end{array}$ & $\begin{array}{l}\text { Measurement through direct } \\
\text { similarity judgments (pair } \\
\text { comparison). }\end{array}$ & $\begin{array}{l}\text { Two samples of individuals } \\
\text { rated two types of stimuli } \\
\text { (automotive and campus } \\
\text { location). Data was } \\
\text { triangulated, aggregated and } \\
\text { then retested on a second } \\
\text { group a month later. Three } \\
\text { perceptual maps were } \\
\text { submitted two weeks later } \\
\text { (individual or aggregated data } \\
\text { maps). For each map, the } \\
\text { subjects rated the map on a } 7- \\
\text { term scale (does not match my } \\
\text { perception or matches my } \\
\text { perception). }\end{array}$ & $\begin{array}{l}\text { In the Summers and MacKay } \\
\text { (1976) experiment, subjects } \\
\text { were unable to identify their } \\
\text { own mapping. Direct } \\
\text { similarity judgments are not a } \\
\text { valid measure of perceptions. } \\
\text { Duplication by Wilkes and } \\
\text { Wilcox (1977) on students } \\
\text { leads to a different conclusion } \\
\text { by rotating mappings (rotated } \\
90^{\circ} \text { compared to the source). } \\
\text { However, the authors stress the } \\
\text { consumers' difficulty in } \\
\text { making a connection between } \\
\text { a perceptual map and a } \\
\text { combination by pairs. }\end{array}$ \\
\hline Lehmann (1972) & $\begin{array}{l}\text { Setting up a procedure for } \\
\text { drawing up a perceptual } \\
\text { mapping based on preferences. }\end{array}$ & $\begin{array}{l}\text { Similarity between two brands } \\
\text { can be seen as the average } \\
\text { probability of replacing one }\end{array}$ & $\begin{array}{l}\text { TORSCA multidimensional } \\
\text { software was used to create a } \\
\text { perceptual map, based on the }\end{array}$ & $\begin{array}{l}\text { Difficulty of using transition } \\
\text { matrices as similarity matrices: } \\
\text { lack of homogeneity of }\end{array}$ \\
\hline
\end{tabular}




\begin{tabular}{|c|c|c|c|c|}
\hline & $\begin{array}{l}\text { Use of a transition matrix as a } \\
\text { similarity matrix. } \\
\text { Studying the influence of } \\
\text { perceived similarity of brands } \\
\text { in cases of replacing a brand } \\
\text { by another. }\end{array}$ & brand by another. & $\begin{array}{l}\text { development of the transition } \\
\text { matrix. Eight soft drinks were } \\
\text { offered to } 264 \text { people during a } \\
\text { 12-month purchase period. } \\
\text { Brand withdrawals and } \\
\text { changes were measured } \\
\text { (transition matrix) and } \\
\text { compared to different } \\
\text { measures of similarity. }\end{array}$ & $\begin{array}{l}\text { individuals studied, problem of } \\
\text { determining purchase periods, } \\
\text { multi-dimensionality of choice } \\
\text { criteria and their weight in } \\
\text { purchasing, search for variety, } \\
\text { etc. }\end{array}$ \\
\hline \multicolumn{5}{|c|}{ Measures of interpersonal similarity } \\
\hline $\begin{array}{l}\text { Bourcier-Bequaert and De } \\
\text { Barnier (2014) }\end{array}$ & $\begin{array}{l}\text { Effects of similarity of } \\
\text { subjective age on the brand in } \\
\text { the advertisement. }\end{array}$ & $\begin{array}{l}\text { Similarity of subjective age of } \\
\text { the model and the receiver acts } \\
\text { directly on overall similarity } \\
\text { (source-receiver) and } \\
\text { indirectly on attitude toward } \\
\text { the brand and on purchase } \\
\text { consideration. }\end{array}$ & $\begin{array}{l}\text { Test of two ads with two } \\
\text { models of different ages, on } \\
221 \text { women aged } 60 \text { to } 70 . \\
\text { Use of measurement scales } \\
\text { developed by Guiot (2001), } \\
\text { Chang (2008) and McKirnan } \\
\text { et al. (1983). }\end{array}$ & $\begin{array}{l}\text { Only the effects of young and } \\
\text { older models were tested on } \\
\text { senior women. Need to test the } \\
\text { effects of a middle-aged model } \\
\text { and consider a broader sample } \\
\text { in terms of age and gender. }\end{array}$ \\
\hline David-Ignatieff (2012) & $\begin{array}{l}\text { Perceived similarity with } \\
\text { regard to an avatar: developing } \\
\text { a measurement scale defining } \\
\text { homophily as the degree of } \\
\text { similarity of interacting agents. }\end{array}$ & $\begin{array}{l}\text { Semantic scale that measures a } \\
\text { multidimensional construct } \\
\text { based on four types of } \\
\text { similarity: similarity of } \\
\text { attitude, educational similarity, } \\
\text { similarity of values, the } \\
\text { similarity of appearance. }\end{array}$ & $\begin{array}{l}\text { Use of a two-dimensional } \\
\text { scale, namely attitude and } \\
\text { appearance (items: the avatar } \\
\text { is very similar to me, } \\
\text { resembles me physically, has } \\
\text { an appearance like mine, } \\
\text { thinks a lot like me). The scale } \\
\text { was tested on } 320 \text { participants } \\
\text { presented with a website with } \\
\text { different versions of avatars. }\end{array}$ & $\begin{array}{l}\text { Problem of confirming the } \\
\text { similarity dimension of values } \\
\text { (the avatar thinks like me). } \\
\text { Only one dimension is used in } \\
\text { the confirmatory analysis } \\
\text { (similarity of appearance). }\end{array}$ \\
\hline \multicolumn{5}{|c|}{ Measures of similarity applied to cross-cultural research } \\
\hline $\begin{array}{l}\text { Watchravesringkan et al. } \\
(2008)\end{array}$ & $\begin{array}{l}\text { Cross-cultural study of the } \\
\text { perception of prices for four } \\
\text { countries in southeast Asia: } \\
\text { China, South Korea, Taiwan } \\
\text { and Thailand. }\end{array}$ & $\begin{array}{l}\text { Use of multi-group } \\
\text { confirmatory factor analysis to } \\
\text { examine the degree of } \\
\text { similarity of price perceptions } \\
\text { in a multicultural context. }\end{array}$ & $\begin{array}{l}\text { On a sample of } 950 \text { students, } \\
\text { revealing five constituent } \\
\text { dimensions of perceived price: } \\
\text { perception of value for money, } \\
\text { sensitivity to prestige, } \\
\text { awareness of value, propensity } \\
\text { to shop, price expertise. }\end{array}$ & $\begin{array}{l}\text { Use of a convenience sample } \\
\text { makes it difficult to generalize } \\
\text { the results. }\end{array}$ \\
\hline Van Auken et al. (2006) & $\begin{array}{l}\text { Cross-cultural study of } \\
\text { cognitive age in order to } \\
\text { identify similarities between }\end{array}$ & $\begin{array}{l}\text { Test of different measurement } \\
\text { scales: a semantic differential } \\
\text { scale, a Likert scale and a ratio }\end{array}$ & $\begin{array}{l}\text { Analysis carried out on two } \\
\text { samples of Japanese and } \\
\text { American seniors. The largest }\end{array}$ & $\begin{array}{l}\text { Difficult to manipulate the } \\
\text { measures because certain } \\
\text { ratings are viewed as abstract }\end{array}$ \\
\hline
\end{tabular}




\begin{tabular}{|c|c|c|c|c|}
\hline & $\begin{array}{l}\text { the different dimensions of the } \\
\text { construct (United States } \\
\text { compared to Japan). }\end{array}$ & scale. & $\begin{array}{l}\text { variance was observed for the } \\
\text { semantic differential scale on } \\
\text { all dimensions of the } \\
\text { construct: cognitive age, ideal } \\
\text { age, least desired age. The } \\
\text { ratio scale shows more } \\
\text { similarity between respondents } \\
\text { than the differential semantic } \\
\text { scale or Likert scale. } \\
\text { The closest similarities are } \\
\text { between Japanese seniors (men } \\
\text { and women) and the greatest } \\
\text { differences between the } \\
\text { Japanese and Americans. }\end{array}$ & by Japanese informants. \\
\hline \multicolumn{5}{|c|}{ Measures of similarity in brand extensions } \\
\hline Völckner and Sattler (2006) & $\begin{array}{l}\text { Analysis of ten factors behind } \\
\text { the success of a brand } \\
\text { extension. }\end{array}$ & & $\begin{array}{l}\text { Five real extensions of } 25 \\
\text { different brands considered, } \\
\text { evaluated by } 2,426 \text { students. } \\
\text { The overall similarity between } \\
\text { the parent brand and its } \\
\text { extensions is incorporated into } \\
\text { a scale measuring fit, as well } \\
\text { as the brand's ability to } \\
\text { achieve the extension. }\end{array}$ & $\begin{array}{l}\text { Questioning by Völckner and } \\
\text { Sattler as to what really } \\
\text { constitutes fit. }\end{array}$ \\
\hline Klink and Smith (2001) & $\begin{array}{l}\text { Analysis of factors affecting } \\
\text { the relation between overall } \\
\text { similarity (fit) and evaluation } \\
\text { of the brand extension. }\end{array}$ & $\begin{array}{l}\text { Factors that modify the } \\
\text { relation between overall } \\
\text { similarity and evaluation of the } \\
\text { brand extension. }\end{array}$ & $\begin{array}{l}\text { Overall similarity between the } \\
\text { parent brand and the extension } \\
\text { category (fit, for these authors) } \\
\text { is measured by a measurement } \\
\text { instrument that simultaneously } \\
\text { brings together all items } \\
\text { describing literal similarity } \\
\text { (characteristics and functions } \\
\text { of the product, manufacturing } \\
\text { process) and items describing } \\
\text { relational similarity (needs } \\
\text { met, usage situations). }\end{array}$ & $\begin{array}{l}\text { Methodological limitation: the } \\
\text { overall similarity construct is } \\
\text { in fact formative (not } \\
\text { reflective) because it is } \\
\text { comprises two types of } \\
\text { similarity. It should therefore } \\
\text { be split up or validated as a } \\
\text { formative construct. Need to } \\
\text { duplicate the analysis with } \\
\text { Broniarczyk and Alba's } \\
\text { (1994) conception of fit. }\end{array}$ \\
\hline Dacin and Smith (1994) & $\begin{array}{l}\text { Possible number, quality and } \\
\text { links of extensions with the }\end{array}$ & $\begin{array}{l}\text { Lack of consistency in the } \\
\text { brand's product portfolio }\end{array}$ & $\begin{array}{l}\text { Similarity between the parent } \\
\text { brand's products and those of }\end{array}$ & $\begin{array}{l}\text { Fictitious extension described } \\
\text { too briefly. }\end{array}$ \\
\hline
\end{tabular}




\begin{tabular}{|c|c|c|c|c|}
\hline & $\begin{array}{l}\text { parent that do not weaken the } \\
\text { parent brand. }\end{array}$ & $\begin{array}{l}\text { reduces appreciation of the } \\
\text { quality of the extension. }\end{array}$ & $\begin{array}{l}\text { its extension measured by } \\
\text { three items (same type of } \\
\text { needs met, same use situations, } \\
\text { physical characteristics of the } \\
\text { products). }\end{array}$ & \\
\hline Smith and Park (1992) & $\begin{array}{l}\text { Analysis of the effects of } \\
\text { brand extensions on market } \\
\text { share and advertising } \\
\text { effectiveness. }\end{array}$ & $\begin{array}{l}\text { Close similarity between the } \\
\text { product and other referent } \\
\text { products of the brands } \\
\text { maximize the effects of the } \\
\text { extension. }\end{array}$ & $\begin{array}{l}\text { Factor analysis of similarity } \\
\text { enabling intrinsic (literal) } \\
\text { similarity and extrinsic } \\
\text { (relational) similarity to be } \\
\text { distinguished. }\end{array}$ & $\begin{array}{l}\text { Because the extensions } \\
\text { analyzed were successful, the } \\
\text { brand's strength score and the } \\
\text { similarity score are too high to } \\
\text { assess whether lower scores } \\
\text { would decrease the effect on } \\
\text { market share. }\end{array}$ \\
\hline Park et al. (1991) & $\begin{array}{l}\text { Analysis of the effects of } \\
\text { literal and relational similarity } \\
\text { on evaluation of brand } \\
\text { extensions. }\end{array}$ & $\begin{array}{l}\text { A functional brand extension } \\
\text { is more favored by similarity } \\
\text { based on product } \\
\text { characteristics, whereas a } \\
\text { prestige brand extension is } \\
\text { favored by similarity based on } \\
\text { more abstract elements. }\end{array}$ & $\begin{array}{l}\text { Evaluation by } 30 \text { individuals } \\
\text { of the similarity between two } \\
\text { brands of watches (Rolex and } \\
\text { Timex) and their extensions. } \\
\text { Blind coding of responses by } \\
\text { two encoders who isolate } \\
\text { literal similarity (product } \\
\text { characteristics, product uses } \\
\text { and functions) and more } \\
\text { relational similarity (functional } \\
\text { or prestigious categories). }\end{array}$ & $\begin{array}{l}\text { Need to duplicate the analysis } \\
\text { on other brands. } \\
\text { Product uses fall more within } \\
\text { the concept of relational } \\
\text { similarity. }\end{array}$ \\
\hline
\end{tabular}




\section{REFERENCES}

Aaker D et Keller K (1990) Consumer evaluations of brand extensions. Journal of Marketing 54 (1): 27-41.

Ahluwalia R (2008) How far can a brand stretch? Understanding the role of self-construal. Journal of Marketing Research 337(45): 337-350.

Alba J et Hutchinson W (1987) Dimensions of consumer expertise. Journal of Consumer Research 13(4): 411-454.

Aurier P (1993) Analyse de la structure des marchés. Le point sur les modèles. Recherche et Applications en Marketing 8(2): 79-104.

Barsalou L (1983) Ad hoc categories. Memory \& Cognition 11(3): 211-227.

Barsalou L (1985) Ideals, central tendency, and frequency of instantiation as determinants of graded structure in categories. Journal of Experimental Psychology: Learning, Memory, and Cognition 11(4): 629-654.

Bassok M et Medin D (1997) Birds of a Feather Flock Together: Similarity Judgments with Semantically Rich Stimuli. Journal of Memory and Language 36 (3): 311-336.

Batra R, Lenk P et Wedel M (2010) Brand extension strategy planning: empirical estimation of brand-category personality fit and atypicality. Journal of Marketing Research 47(2): 335347.

Bèzes C (2010) Tout ce qui est congruent, est-il similaire ? Propositions de définition du

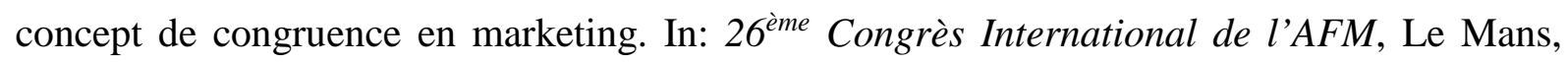
France, Mai 2010.

Bèzes C (2013) Effect of channel congruence on a retailer's image. International Journal of Retail \& Distribution Management 41(4): 254-273.

Bèzes C et Dubois P-L (2013) A conceptual and empirical distinction between the concepts of congruence and fit: the example of retailer extensions. In: La Londe Consumer Behavior Conference, La Londe les Maures, France, Juin 2013.

Bourcier-Bequaert B et De Barnier V (2014) Les effets de l'âge du mannequin sur les consommateurs seniors et sur la marque présente dans la publicité : le rôle de la similarité. Décisions Marketing 76: 77-92.

Boush D (1997) Brand name effects on interproduct similarity judgments. Marketing Letters 8(4): 419-427.

Boush D, Shipp S, Loken B, Gencturk E, Crockett S, Kennedy E, Minshall B, Misurell D, Rochford L et Strobel J (1987) Affect generalization to similar and dissimilar brand extensions. Psychology \& Marketing 4(3): 225-237. 
Bridges S (1989) A schema unification model of brand extensions. Advances in Consumer Research 19(1): 257-258.

Bridges S, Keller K et Sood S (2000) Communication strategies for brand extensions : enhancing perceived fit by establishing explanatory links. Journal of Advertising 39(4) : 1-11. Broniarczyk S et Alba J (1994) The importance of the brand in brand extension. Journal of Marketing Research 31(2): 214-228.

Brudvig S et Raman P (2006) The impact of fit and goal congruency on consumers' attitude to brand extensions. Marketing Management Journal 16(2): 171-178.

Bruner J et Postman L (1949) On the perception of incongruity: a paradigm. Journal of Personality 18(2): 206-223.

Byrne D et Griffitt W (1973) Interpersonal attraction. Annual Review of Psychology 24(1): 317-336.

Byrne D, Griffitt W et Stefaniak D (1967) Attraction and similarity of personality characteristics. Journal of Personality and social Psychology 5(1): 82-90.

Cech C (1989) Congruity and the expectancy hypothesis. Journal of Experimental Psychology: Learning, Memory, and Cognition 15(6): 1129-1133.

Cegarra J-J et Merunka D (1993) Les extensions de marque : concepts et modèles. Recherche et Applications en Marketing 8(1): 53-76.

Chandon J-L et Strazziéri A (1986) Une analyse de structure de marché sur la base de la mesure de l'ensemble évoqué. Recherche et Applications en Marketing 1(1): 17-39.

Cohen J et Basu K (1987) Alternative models of categorization: toward a contingent processing framework. Journal of Consumer Research 13(4): 455-472.

Collange V (2005) L'impact du changement de nom de marque sur l'attitude vis-à-vis du produit. Thèse de Doctorat en Sciences de Gestion, Université Paul Cézanne Aix-Marseille 3. Corfman K (1991) Comparability and comparison levels used in choices among consumer products. Journal of Marketing Research 28(3): 368-374.

Creusen M et Schoormans J (1997) The nature of differences between similarity and preference judgements: A replication with extension. International Journal of Research in Marketing 14(1): 81-87.

Cunha M et Laran J (2008) Asymmetries in the sequential learning of brand associations: Implications for the early entrant advantage. Journal of Consumer Research 35(5): 788-799.

Czellar S (2003) Consumer attitude toward brand extensions: an integrative model and research propositions. International Journal of Research in Marketing 20: 97-115. 
Dacin P et Smith D (1994) The effect of brand portfolio characteristics on consumer evaluations of brand extensions. Journal of Marketing Research 31(2): 229-242.

Damak L (1997) Corps du consommateur et design du produit: recherche d'une similarité ou d'une complémentarité? In: Cahier de Recherche 257, Centre de Recherche DMSP, Paris Dauphine.

David-Ignatieff A (2012) Détermination de l'âge idéal de l'avatar en fonction de l'âge de l'internaute cible du site Internet. Thèse de Doctorat, HEC Montréal, Canada.

Derbaix C et Sjöberg L (1994) Movie stars in space: A comparison of preference and similarity judgments. International Journal of Research in Marketing 11(3): 261-274. Dimitriadis S (1993) L'extension des marques et des enseignes : cadre conceptuel et problématique managériale. Recherche et Applications en Marketing 8(3): 21-44.

Douglas S et Craig S (1996) Executive insights: global portfolio planning and market interconnectedness. Journal of International Marketing 4(1): 93-110.

Dröge C et Darmon R (1987) Associative positioning strategies through comparative advertising: Attribute versus overall similarity approaches. Journal of Marketing Research 24(4): 377-388.

Dubé L et Schmitt B (1999) The effect of a similarity versus dissimilarity focus in positioning strategy: the moderating role of consumer familiarity and product category. Psychology \& Marketing 16(3): 211-224.

Estes Z, Gibbert M, Guest D et Mazursky D (2012) A dual-process model of brand extension: taxonomic feature-based and thematic relation-based similarity independently drive brand extension evaluation. Journal of Consumer Psychology 22(1): 86-101.

Fiske S, Neuberg S, Beattie A et Milberg S (1987) Category-based and attribute-based reactions to others: some informational conditions of stereotyping and individuating process. Journal of Experimental Social Psychology 23(5): 399-427.

Fry J et Claxton J (1971) Semantic differential and nonmetric multidimensional scaling descriptions of brand images. Journal of Marketing Research 8(2): 238-240.

Galan J-P (2009) Musique et réponses à la publicité : effets des caractéristiques, de l'appréciation et de la congruence musicales. Recherche et Applications en Marketing 24(4) : 3-21.

Gefen D et Straub D (1997) Gender differences in the perception and use of e-mail: An extension to the Technology Acceptance Model. MIS Quarterly 21(4): 389-400.

Gentner D (1988) Metaphor as structure mapping: the relational shift. Child Development 59: 47-59. 
Gentner D et Gunn V (2001) Structural alignment facilitates the noticing of differences. Memory \& Cognition 29(4): 565-577.

Gentner D et Markman A (1994) Structural alignment in comparison: no difference without similarity. Psychological Science 5(3): 152-158.

Gentner D et Markman A (1997) Structure mapping in analogy and similarity. American Psychologist 52(1): 45-56.

Gill T et Dubé L (2007) What is a leather iron or a bird phone? Using conceptual combinations to generate and understand new product concepts. Journal of Consumer Psychology 17(3): 202-217.

Goldstone R, Medin D et Gentner D (1991) Relational similarity and the non-independence of features in similarity judgments. Cognitive Psychology 23(2): 222-262.

Goodman N (1972) Seven strictures on similarity. Problems and Projects. New-York, BobsMerill.

Green P, Rao V et Desarbo W (1978) Incorporating group-level similarity judgments in conjoint analysis. Journal of Consumer Research 5(3): 187-193.

Gregan-Paxton J et John R (1997) Consumer learning by analogy: a model of internal knowledge transfer. Journal of Consumer Research 24 (3): 266-284.

Grein A (2000) The impact of market similarity on international marketing strategies: The automobile industry in western Europe. International Business Review 42(2): 167-186.

Hassanein K et Head M (2006) The impact of infusing social presence in the web interface: An investigation across product types. International Journal of Electronic Commerce 10(2): $31-55$.

Heckler S et Childers T (1992) The role of expectancy and relevancy in memory for verbal and visual information: what is incongruency? Journal of Consumer Research 18: 475-492.

Hem L et Iversen N (2002) Decomposed similarity measures in brand extensions. Advances in Consumer Research 29: 199-206.

Hem L et Iversen N (2009) Effects of different types of perceived similarity and subjective knowledge in evaluations of brand extensions. International Journal of Market Research 51(6): 797-818.

Herr P, Farquhar P et Fazio R (1996) Impact of dominance and relatedness on brand extensions. Journal of Consumer Psychology 5(2): 135-159.

Hirschmann E (1980) Innovativeness, novelty seeking, and consumer creativity. Journal of Consumer Research 7(3): 283-295. 
Hofstede F, Wedel M et Steenkamp J-B (2002) Identifying spatial segments in international markets. Marketing Science 21(2): 160-77.

Hollingworth H (1913) Judgments of similarity and difference. Psychological Review 20(4): 271-289.

Hutchinson J et Alba J (1991) Ignoring irrelevant information: situational determinants of consumer learning. Journal of Consumer Research 18(3): 325-345.

Jain A et Pinson C (1976) The effect of order of presentation of similarity judgments on multidimensional scaling results: an empirical examination. Journal of Marketing Research 13(4): 435-439.

Jiang L, Hoegg J, Dahl D et Chattopadhyay A (2010) The persuasive role of incidental similarity on attitudes and purchase intentions in a sales context. Journal of Consumer Research 36(5): 778-791.

Johnson M (1981) Context effects in product perception. Advances in Consumer Research, 8(1): 112-115.

Johnson M (1984) Consumer choice strategies for comparing non comparable alternatives. Journal of Consumer Research 11(3): 741-753.

Johnson M et Horne D (1987) Subject/referent positioning in comparative advertising: a pilot study. Advances in Consumer Research 14(1): 164-167.

Johnson M et Horne D (1988) The contrast model of similarity and comparative advertising. Psychology \& Marketing 5(3): 211-232.

Johnson M et Hudson E (1996) On the perceived usefulness of scaling techniques in market analysis. Psychology \& Marketing 13(7): 653-675.

Kamins M et Gupta K (1984) Congruence between spokesperson and product type: a matchup hypothesis perspective. Psychology \& Marketing 11(6): 569-586.

Kellaris J, Cox A et Cox D (1993) The effect of background music on ad processing: a contingency explanation. Journal of Marketing 57: 114-125.

Keller K et Aaker D (1992) The effects of sequential introduction of brand extensions. Journal of Marketing Research 29(1): 35-50.

Khan M et Paivio A (1988) Memory for schematic and categorical information: a replication and extension of Rabinowitz and Mandler. Journal of Experimental Psychology: Learning, Memory and Cognition 14(3): 558-561.

Kim J et Parkhe A (2009) Competing and cooperating similarity in global strategic alliances: An exploratory examination. British Journal of Management 20(3): 363-376. 
Kirmani A et Shiv B (1998) Effects of source congruity on brand attitudes and beliefs: the moderating role of issue-relevant elaboration. Journal of Consumer Psychology 7(1): 25-47. Klink R et Smith D (2001) Threats to the external validity of brand extension research. Journal of Marketing Research 38(3): 326-335.

Kruhmans C (1978) Concerning the applicability of geometric models to similarity data: The interrelationship between similarity and spatial density. Psychological Review 85(5): 445-163. Kwon H et Ha S (2013) The effects of perceived similarity with others on shopping mall satisfaction. Society for Marketing Advances Proceedings 25: 249-250.

Law S (2002) Can repeating a brand claim lead to memory confusion? The effects of claim similarity and concurrent repetition. Journal of Marketing Research 39(3): 366-378.

Lazarsfeld PF et Merton R (1954) Friendship as a social process: a substantive and methodological analysis. In : Morroe B, Abel T and Page C (eds) Freedom and control in modern society. New York: VanNostrand, pp. 18-66.

Lehmann D (1972) Judged similarity and brand-switching data as similarity measures. 9(3): 331-334.

Leibniz G (1995) La caractéristique géométrique. traduit par M. Parmentier, Vrin.

Lemoine J-F et Chérif E (2012) Comment générer de la confiance envers un agent virtuel à l'aide de ses caractéristiques? Une étude exploratoire. Management \& Avenir 58: 169-188.

Loken B (2006) Consumer psychology: categorization, inferences, affect, and persuasion. Annual Review of Psychology 57 : 453-485.

Maille V (2007), L'intensité du goût et de la couleur de produits alimentaires : l'influence de l'incongruence perçue sur l'acceptabilité. Actes du $23^{\text {ème }}$ Congrès International de l'AFM, Aix-les-Bains, France, Mai 2007, pp.1-25.

Maille V et Fleck N (2011) Congruence perçue par le consommateur : vers une clarification du concept, de sa formation et de sa mesure. Recherche et Applications en Marketing 26(2): 77-111.

Mandler G (1982) The structure of value: accounting for taste. In: M.S. Clark et S.T. Fiske (cood), Affect and Cognition: Annual Carnegie Symposium, 17, Hillsdale, Lawrence Erlbaum Associates, pp. 3-36.

Mao H, Mariadoss B, Echambadi R et Chennamaneni P (2012) Brand extensions via complements or substitutes: The moderating role of manufacturing transferability. Marketing Letters 23(1): 279-292. 
Markman A et Wisniewski E (1997) Similar and different: the differentiation of basic-level categories. Journal of Experimental Psychology: Learning, Memory, and Cognition 23(1): 54-70.

Martin I et Stewart D (2001) The differential impact of goal congruency on attitudes, intentions, and the transfer of brand equity. Journal of Marketing Research 38(4): 471-484.

McCroskey J C et Richmond V P (1990) Willingness to communicate: Differing cultural perspectives. Southern Journal of Communication, 56(1): 72-77.

Medin D et Smith E (1984) Concepts and concept formation. Annual Review of Psychology, 35: 113-138.

Medin D, Goldstone R et Gentner D (1990) Similarity involving attributes and relations: judgments of similarity and difference are not inverses. Psychological Science 1(1): 64-69.

Medin D, Goldstone R et Gentner D (1993) Respects for similarity. Psychological Review 100(2): 254-278.

Mednick S et Mednick M (1962) Remote associates test. Boston: Houghton Mifflin.

Mercanti-Guérin M (2010) L'écosystème des sites de vente en ligne : une analyse par le Web

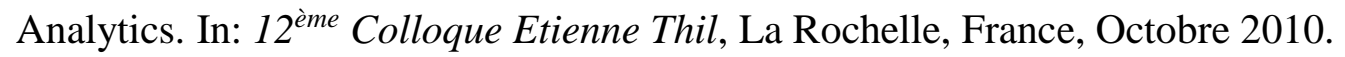

Meyers-Levy J, Louie T et Curren M (1994) How does the congruity of brand names affect evaluations of brand name extensions? Journal of Applied Psychology 79(1): 46-53.

Meyers-Levy J, et Tybout A (1989) Schema congruity as a basis for product evaluation. Journal of Consumer Research 16(1): 39-54.

Monga A B et John DR (2010) What makes brands elastic? The influence of brand concept and styles of thinking on brand extension evaluation. Journal of Marketing 74(3) : 80-92.

Monga A et Gürhan-Canli Z (2012) The influence of mating mind-sets on brand extension evaluation. Journal of Marketing Research 49(4): 581-593.

Monneret P, (2014) Motivation et analogie, Enjeux de la similarité en sciences du langage. Philologia, (56): 27-38.

Moon Y (2000) Intimate exchanges: using computers to elicit self-disclosure from consumers. Journal of Consumer Research 26(4): 323-339.

Mori M (1970) The uncanny valley. Energy 7: 33-35.

Murphy G et Medin D (1985) The role of theories in conceptual coherence. Psychological Review 92(3): 289-316.

Nass C, Moon Y, Fogg B, Reeves B et Dryer C (1995) Can computer personalities be human personalities? International Journal of Human-Computers Studies 43(2): 223-239. 
Neidell L (1972) Procedures for obtaining similarities data. Journal of Marketing Research 9(3): 335-337.

Nowak K (2004) The influence of anthropomorphism and agency on social judgment in virtual environments. Journal of Computer Mediated Communication 9(2).

Ortony A (1979) Beyond literal similarity. Psychological Review 86(3): 161-180.

Ozanne J, Brucks M et Grewal D (1992) A study of information search behavior during the categorization of new products. Journal of Consumer Research 18(4): 452-463.

Park C, Lawson R et Milberg S (1989) Memory structure of brand names. Advances in Consumer Research 16: 726-731.

Park C, Milberg S et Lawson R (1991) Evaluation of brand extensions: the role of product feature similarity and brand concept consistency. Journal of Consumer Research 18(2): 185193.

Pavelchak M (1989) Piecemeal and category-based evaluation: an idiographic analysis. Journal of Personality and Social Psychology 56(3): 354-363.

Pham M (1996) Heuristiques et biais décisionnels en marketing. Recherche et Applications en Marketing 11(4): 53-69.

Poncin I, Pieters R et Ambaye M (2006) Cross-advertisement affectivity: The influence of similarity between commercials and processing modes of consumers on advertising processing. Journal of Business Research 59(6): 745-754.

Rangaswamy A, Burke R et Oliva T (1993) Brand equity and the extendibility of brand names. International Journal of Research in Marketing 10(1): 61-75.

Ratneshwar S et Shocker A (1991) Substitution in use and the role of usage context in product category structures. Journal of Marketing Research 28(3): 381-395.

Ratneshwar S, Barsalou L, Pechmann C et Moore M (2001) Goal-derived categories: the role of personal and situational goals in category representations, Journal of Consumer Psychology 10(3): 147-157.

Reed H (1927) The essential laws of learning or association. Psychological Review 34(2): 107-115.

Rips L et Collins A (1993) Categories and resemblance. Journal of Experimental Psychology General 122(4): 468-486.

Rips L, Shoben E et Smith E (1973) Semantic distance and the verification of semantic relations. Journal of Verbal Learning and Verbal Behavior 12(1): 1-20.

Rosch E, Mervis C, Gray W, Johnson D et Boyes-Braem P (1976) Basic objects in natural categories. Cognitive Psychology 8: 382-439. 
Saaksjarvi M et Pulkkinen E (2009) The category label and overall similarity in hybrid products: matches/mismatches and categorization asymmetry in consumer preferences. Advances in consumer research 36: 795-796.

Sar S, Duff B et Anghelcev G (2011) If you feel it now you will think it later: The interactive effects of mood over time on brand extension evaluations. Psychology \& Marketing 28(6): 561-583.

Schmitt B et Dubé L (1992) Contextualized representations of brand extensions: Are feature lists or frames the basic components of consumer cognition? Marketing Letters 3(2): 115-126. Schützwohl A (1998) Surprise and schema strength. Journal of Experimental Psychology: Learning, Memory, and Cognition 24(5): 1182-1199.

Schweidel D, Bradlow E et Williams P (2006) A feature-based approach to assessing advertisement similarity. Journal of Marketing Research 43(2): 237-243.

Seltène M (2004) Processus d'évaluation de l'extension de marque par le consommateur : conception et validation d'un modèle de décomposition. Recherche et Applications en Marketing, 19(1): 3-24.

Shanon B (1988) On similarity of features. New Ideas in Psychology 6(3): 307-321.

Shepard R (1962) The analysis of proximities: multidimensional scaling with an unknown distance function. Psychometrika 27(2): 125-140.

Sirgy J (1982) Self-concept in consumer behavior: a critical review. Journal of Consumer Research 9: 287-300.

Smith DC et Park CW (1992) The effects of brand extensions on market share and advertising efficiency. Journal of Marketing Research 29: 296-313.

Stayman D, Alden D et Smith K (1992) Some effects of schematic processing on consumer expectations and disconfirmation judgments. Journal of Consumer Research 19(2): 240-255.

Sujan M (1985) Consumer knowledge: effects on evaluation strategies mediating consumer judgments. Journal of Consumer Research 12(1): 31-46.

Sujan M, Bettman J et Sujan H (1986) Effects of consumer expectations on information processing in selling encounters. Journal of Marketing Research 23(4): 346-353.

Swartz T (1984) Relationship between source expertise and source similarity in an advertising context. Journal of Advertising 13(2): 49-55.

Tauber E (1988) Brand leverage strategy for growth in a cost-control world. Journal of Advertising Research 28(4): 26-30. 
Taylor V et Bearden W (2002) The effects of price on brand extension evaluations: the moderating role of extension similarity. Journal of the Academy of Marketing Science 30(2): 131-140.

Thibaut J-P (1997) Similarité et catégorisation. L'année psychologique 97(4): 701-736.

Thompson D et Malaviya P (2013) Consumer-generated ads: does awareness of advertising co-creation help or hurt persuasion? Journal of Marketing 77(3): 33-47.

Thompson M et Zanna M (1995) The conflicted individual: personality-based and domainspecific antecedents of ambivalent social attitudes. Journal of Personality 63(2): 259-288.

Tversky A (1977) Features of similarity. Psychological Review 84(4): 327-352.

Tversky A et Gati I (1982) Similarity, separability, and the triangle inequality. Psychological Review 89(2): 123-154.

Van Auken S, Barry T et Bagozzi R (2006) A cross-country construct validation of cognitive age. Journal of the Academy of Marketing Scienc, 34(3): 439-455.

Völckner F et Sattler H (2006) Drivers of brand extension success. Journal of Marketing 70(2):18-34.

Watchravesringkan K, Yan R-N et Yurchisin J (2008) Cross-cultural invariance of consumers' price perception measures: Eastern Asian perspective. International Journal of Retail \& Distribution Management 36(10): 759-779.

Wilkes R et Wilcox J (1977) On the validity and reliability of direct similarity judgements: A comment. Journal of Marketing Research 14(2): 261-262.

Wilkie W et Farris P (1975) Comparison advertising: Problems and potential. Journal of Marketing 39(4): 7-15.

Zajonc R (1980) Feelings and thinking: preferences need no inferences. American Psychologist 35(2): 151-175.

Zhang X, Li S, Burke R et Leykin A (2014) An examination of social influence on shopper behavior using video tracking data. Journal of Marketing 78(5): 24-41. 